Revta brasil. Bot., São Paulo, V.23, n.4, p.451-457, dez. 2000

\title{
Ultrastructure of the intercellular protuberances in leaves of Paepalanthus superbus Ruhl. (Eriocaulaceae)
}

\author{
SILVIA RODRIGUES MACHADO ${ }^{1,4}$, MARIA EMÍLIA M. ESTELITA ${ }^{2}$ \\ and ELISA APARECIDA GREGÓRIO ${ }^{3}$
}

(received: March 10, 2000; accepted: September 13, 2000)

\begin{abstract}
Ultrastructure of the intercellular protuberances in leaves of Paepalanthus superbus Ruhl. (Eriocaulaceae)). Mature leaves of Paepalanthus superbus exhibit intercellular protuberances between the inner periclinal walls of the epidermal and the parenchyma cells surface, as well as on the surface of the parenchyma mesophyll cells. These structures are mostly prominent around the parenchyma cells, forming a gel capsule-like structure. Histochemical tests with ruthenium red indicate the pectic nature of the intercellular deposits, with scattered lipidic inclusions as revealed by sudan IV and sudan black B. Ultrastructural analyses show a fibrillar matrix with scattered fimbriate and tubular structures, and a distinct margin delimited by a dense membrane-like structure. Our results suggest that the protuberances are derived from secretory activity, and are formed after the development of the intercellular spaces. For $P$. superbus this structure may represent an important cell wall specialisation, related with the adhesion and transport mechanisms between cells.
\end{abstract}

RESUMO - (Ultra-estrutura de protuberâncias intercelulares em folhas de Paepalanthus superbus Ruhl. (Eriocaulaceae)). Folhas adultas de Paepalanthus superbus mostram protuberâncias intercelulares, entre a parede periclinal interna das células epidérmicas e superfície de células parenquimáticas; depósitos semelhantes ocorrem na superfície das células parenquimáticas do mesofilo. Estas protuberâncias são mais proeminentes ao redor de células parenquimáticas, formando uma estrutura que lembra uma cápsula gelatinosa. Testes histoquímicos com vermelho de rutênio evidenciam sua natureza péctica, com inclusões lipídicas dispersas, detectadas por sudan IV e sudan black B. Ultra-estruturalmente as protuberâncias mostram matriz fibrilar permeadas por estruturas fimbriadas e tubulares, com margem distinta formada por estrutura membranosa. Nossos resultados sugerem que estas protuberâncias são derivadas de atividade secretora, sendo formadas após o desenvolvimento dos espaços intercelulares. Em $P$. superbus esta estrutura pode representar uma especialização da parede celular, relacionada com adesão e mecanismos de transporte entre células.

Key words - Paepalanthus superbus, ultrastructure, intercellular protuberance, leaf, Eriocaulaceae

\section{Introduction}

Intercellular pectin protuberances of varying morphological patterns are of widespread occurrence in different taxa and plant tissues (Carlquist 1956, Carr \& Carr 1975, Parameswaran 1976, Heide-Jrgensen 1978, Potgieter \& van Wyk 1992, Machado \& Sajo 1996). Although certain morphological aspects of the intercellular projections on mesophyll cell walls are relatively well documented (Potgieter \& van Wyk 1992), there are controversies over the cell wall protuberances concerning their

1. Departamento de Botânica, Instituto de Biociências, Universidade Estadual Paulista, Câmpus de Botucatu, Caixa Postal 510, 18618-000 Botucatu, SP, Brazil.

2. Departamento de Botânica, Instituto de Biociências, Universidade de São Paulo, Caixa Postal 11461, 05422-970 São Paulo, SP, Brazil.

3. Centro de Microscopia Eletrônica, Instituto de Biociências, Universidade Estadual Paulista, Campus de Botucatu, SP, Caixa Postal 510, 18618-000 Botucatu, SP, Brazil.

4. Corresponding author: botanica@ibb.unesp.br origin, chemical composition, and biological functions. Some authors believe that these structures are produced only as a mechanical consequence of intercellular space development, with no obvious function (Parameswaran 1976, Carr \& Carr 1975, Heide-Jrgensen 1978). Others believe that they are formed by secretion through submicroscopic "wall pores" after the formation of the intercellular spaces (Carr \& Carr 1975). Progress have been made on the ultrastructural and chemical aspects of the protuberances that develop on the surfaces of the callus cells (Davies \& Lewis 1981) and on embryoid cell surfaces (Dubois et al. 1991, 1992, Verdus et al. 1993). Ultrastructural and histochemical studies have shown extracellular accumulations of oil drops in the projections developed on the surface of wound callus cells of Daucus carota (Davies \& Lewis 1981) and extracellular secretion of lipo-glyco-protein with tubular structure on the cell surfaces of the Cichorium mesophyll proembryoides (Verdus et al 1993).

Paepalanthus superbus is a herbaceous plant that grows on rocky soils of the Brazilian vegetation called "campos rupestres", which literally means 
stone fields. Plants from "campos rupestres" are adapted to high light intensities, temporary damp substrate, periods of water deficit, and low nutritional and $\mathrm{pH}$ levels (Giulietti \& Pirani 1988).

In this paper, the occurrence and ultrastructural aspects of the intercellular protuberances in $P$. superbus leaves are described.

\section{Material and methods}

Mature leaves were obtained from plants of $P$. superbus growing in the greenhouse of the Departamento de Botânica, Instituto de Biociências, Universidade de São Paulo, Brazil.

Samples from the median region of these leaves were fixed in $2.5 \%$ glutaraldehyde, post-fixed in $1 \%$ osmium tetroxide, and embedded in Araldite resin. Ultra-thin sections were double stained with uranyl acetate and lead citrate, and examined with a transmission electron microscope (TEM). For the histochemical tests, freehand sections of fresh material were treated with ruthenium red for pectic material and sudan black B and sudan IV for the detection of lipids (Jensen 1962) and examined under a light microscope.

\section{Results}

In $P$. superbus the epidermis is uniseriate and the mesophyll is composed of irregularly spaced parenchyma cells. Pronounced protuberances are observed both on the surface of the inner periclinal walls of the epidermal cell and on the parenchyma mesophyll cell surfaces (figure 1). In both tissues, these structures project into the intercellular spaces and fill the space between adjacent cells (figures 1-3). So, the apparent fusion of the deposits forms bridges across the intercellular space (figures 2 and $3)$. The histochemical test with ruthenium was positive, indicating the pectic nature of the deposited material.

The surface of many parenchyma cells seems to be frequently covered with masses of electron-lucent material forming a gel capsule-like structure (figure 4). There is a margin outlining the protuberances, with distinct organisation and electron-density (figures 2, 4). At higher magnifications, the protuberance is seen to be composed of a finely electron-dense fibrillar network matrix (figure 7) with scattered short tubular and fimbriate structures (figure 6). Both the tubular and the fimbriate structures seem to be attached to the outside of the cell wall (figure 5) and to the protuberance margin (figure 6).

There are regions along the margin of the protuberances with a narrow electron-lucent line at the interface of the adjoining protuberances (figures 8 and 9). The deposits connecting adjacent cells show a convoluted margin of electron-dense material outlined by a trilamelate membrane-like structure (figure 9).

Frequently, the cells with conspicuous intercellular deposits show a large spherical nucleus, dense ribosomal content, plastids with starch and lipidic globules, numerous peroxisomes with a paracristalline zone, mitochondria with prominent cristae, and electron-dense inclusions (figure 10).

Drops or clumps of strongly electron-dense material are seen adjacent to the outer side of the cell wall (figures 2-4, 11 and 12), scattered in the fibrillar matrix (figure 4) or accumulated on the margin of the intercellular protuberance (figure 3). Histochemical tests revealed the lipophilic nature of these materials, as shown by sudan IV and sudan black B reactions.

Parenchyma cells bearing large protuberances show numerous plasmodesmata with prominent pore channel on the outside of the cell wall, as seen in tangential sections (figure 12). These plasmodemata are intact and show plasma membrane, desmotubule, and well-preserved central rod (figure 13).

\section{Discussion}

The ultrastructural features of the intercellular protuberances in $P$. suberbus leaves are similar to those described on the surface cells of proembryoids by Verdus et al. (1993). Histochemical tests detected pectic and lipophilic components in the protuberances. The pectic substances are the major constituents of the intercellular protuberances, as detected by ruthenium red. These substances, which are of considerable importance both for their biological functions and technological exploitation, form gels under conditions of extensive hydration (Morris et al. 1982).

Mesophyll parenchyma cells bearing conspicuous deposits usually showed ultrastructural features indicative of secretory activity. Our observations suggest that the occurrence of secretory activity is 


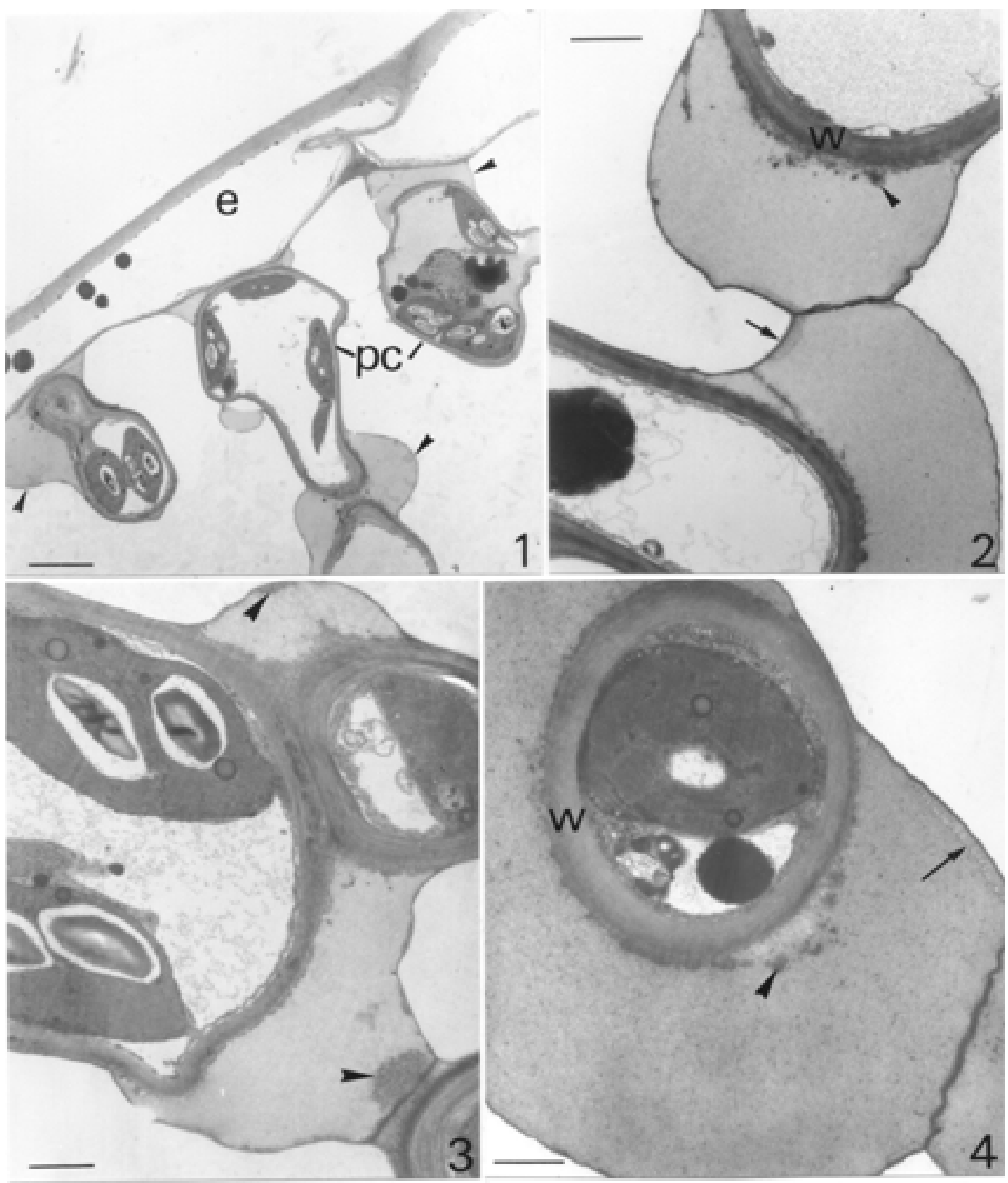

Figures 1-4. TEM of Paepalanthus superbus leaf. 1. Transversal section. Epidermal cell (e); parenchyma cells (pc). The arrowheads indicate the extracellular deposits. Bar $=4 \mu \mathrm{m}$. 2. Protuberances connecting adjacent parenchyma cells with structured electron-dense margins (arrow) and clumps of dense material (arrowhead) near the cell wall (W). Bar $=1 \mu \mathrm{m}$. 3. Clumps of electron-dense material (arrowheads) adjacent to the margin protuberance. $\mathrm{Bar}=1 \mu \mathrm{m}$. 4. Pronounced intercellular protuberance showing a finely electron-dense fibrillar matrix and distinct structured margins (arrow). Note clumps of dense material attached to the outer side of the cell wall (W) surface or scattered throughout the fibrillar matrix (arrowhead). Bar $=0.5 \mu \mathrm{m}$. 

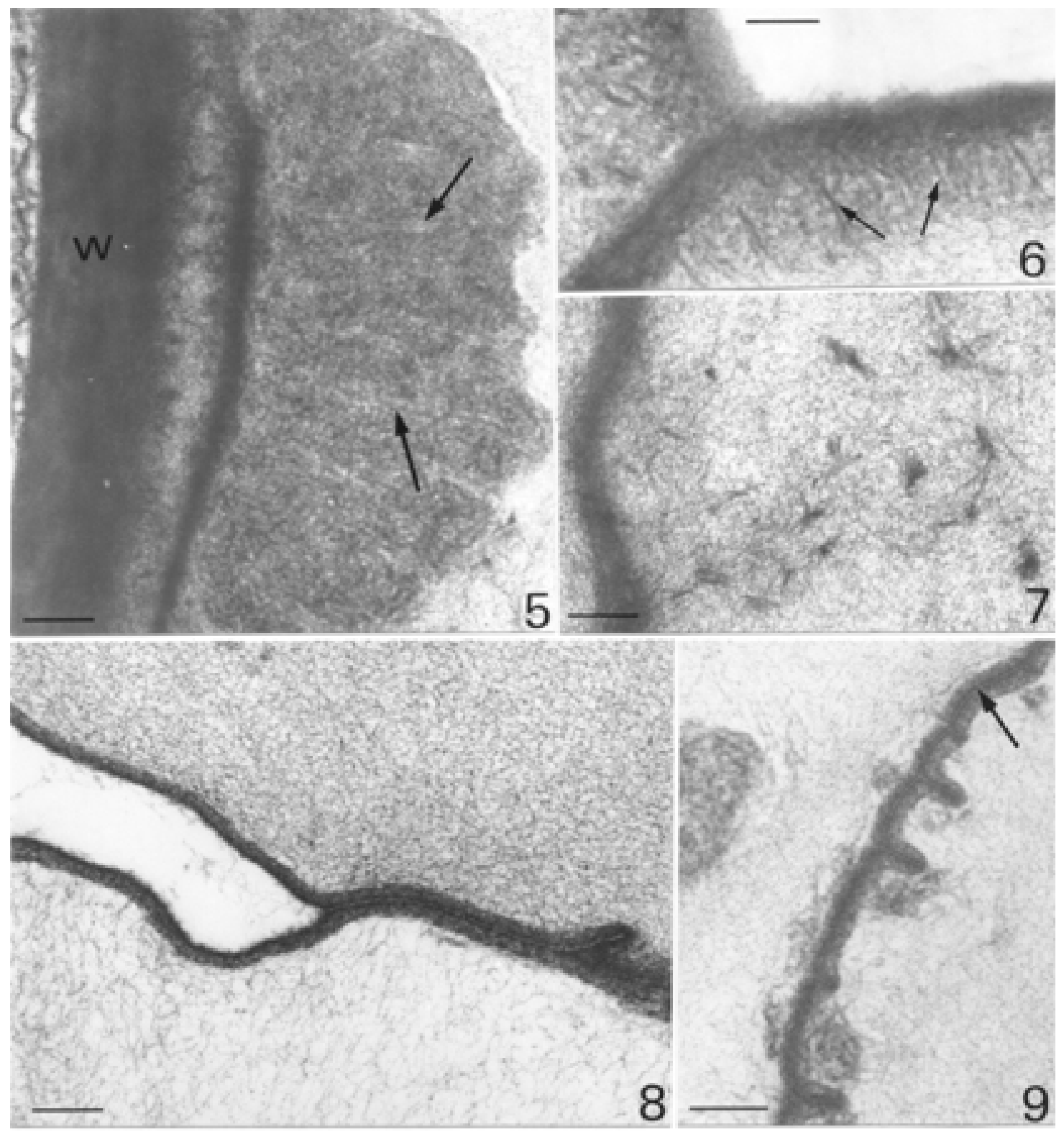

Figures 5-9. TEM of Paepalanthus superbus leaf. 5. Tubular structures (arrows) into the dense material attached to the outer side of the cell wall (W). Bar $=1.0 \mu \mathrm{m}$. 6. Protuberance lateral margin showing tubular and fimbriate structures (arrows). Bar $=0.1 \mu \mathrm{m}$. 7. Detail of the deposit with scattered short tubular and fimbriate structures. Bar $=0.2 \mu \mathrm{m}$. 8. Electron-dense margins of adjacent cells. Bar $=0.2 \mu \mathrm{m}$. 9. Convoluted protuberance margin with an electron-lucent line (arrow) connecting adjacent cells. Bar $=0.2 \mu \mathrm{m}$.

associated with the production and excretion of some components of the intercellular deposits, as described by Davies \& Lewis (1981). Extracellular accumulation of oil droplets in the projections was observed by Davies \& Lewis (1981) on the surface of wound callus cells of Daucus carota. According to these authors, the oil deposits may play a role in cell adhesion, suberization, or plant defence against pathogen infection. 


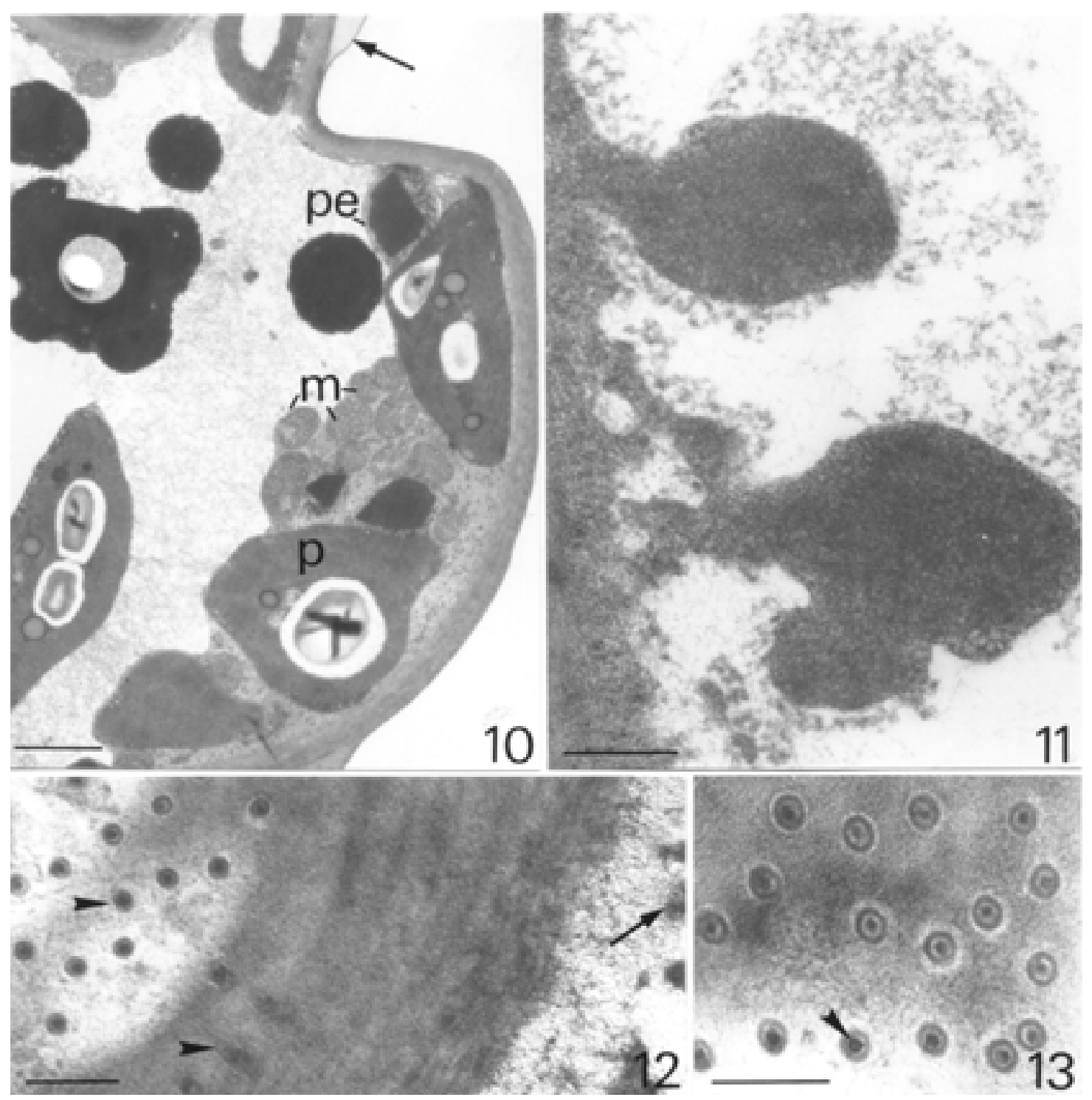

Figures 10-13. TEM of Paepalanthus superbus leaf. 10. Parenchyma cell with intercellular protuberance (arrow); plastid (p), mitochondria $(\mathrm{m})$, peroxisomes (pe). Bar $=0.2 \mu \mathrm{m}$. 11. Clumps of electron-dense material adjacent to the cell wall surface. $B a r=0.2$ $\mu \mathrm{m}$. 12. Tangential section of the parenchyma cell wall showing plasmodesmata (arrowheads). The arrow indicates a clump of electron-dense material scattered throughout the fibrillar matrix of the protuberance. $B a r=0.2 \mu \mathrm{m}$. 13. Detail of the parenchyma cell wall showing plasmodesmata with prominent pore channels. The arrowhead indicates a desmotubule. $\mathrm{Bar}=0.1 \mu \mathrm{m}$.

A membrane-like structure outlining the intercellular protuberance was also observed by Davies \& Lewis (1981). This membrane may be similar to the internal cuticle observed by Heide-Jrgensen (1978), outlining the intercellular pectic strands of the xeromorphic mesophyll leaves of Hakea suaveolens. Internal cuticles have been seen in sev- eral species with large exposed surface area of chlorenchyma cells, being related with lower transpiration rates (Cutler 1966).

The presence of intact plasmodesmata in the parenchyma cells connected by the protuberances can be related to the symplastic movement of ions between adjacent cells (Carr et al. 1980), the secre- 
tion of extracellular materials, and the transcellular distribution of cytoskeleton, as observed by Zhang et al. (1998) in endosperm cells of Triticum aestivum. Prominent plasmodesmata were also observed by Konar et al. (1972) in the thick-walled embryogenic cells of Ranunculus sceleratus. Remains of stretched plasmodesmata were observed on the anticlinal walls of palisade cells by Heide-Jørgensen (1978). These broken plasmodesmata were interpreted by the author as a result of the middle lamella separation during the projection development. Our observations indicate that intercellular protuberances in $P$. superbus are formed by secretion of materials through plasmodesmata after the development of intercellular spaces, according to Schenck hypothesis (see Carr \& Carr 1975).

Although protein histochemical tests have not been performed in $P$. superbus, ultrastructural analysis of the intercellular deposits revealed fibrillar and tubular structures similar to those described by Verdus et al. (1993). Histochemical reactions performed by these authors revealed a lipo-glyco-protein of tubular structure.

The occurrence of glycoproteins and other related proteins in cell walls and extracellular fluids are widely documented in several plant species. These proteins have been related with cell adhesion and recognition, wound healing, and plant defence (Showalter 1993). In addition, some structural proteins are located in the middle lamella and intercellular spaces of the cortex, and may act as a cement to these cells (Keller 1993). According to Ruoslahti \& Pierschbacher (1987), this intercellular deposits may show similarity to animal cells, where surface glycoproteins of the extracellular matrix play a role in adhesion and recognition, being linked to the cytoskeleton.

Possible biological functions of the intercellular protuberances in $P$. superbus leaves may be suggested. So, the apparent fusion of the protuberances to form bridges across the intercellular space suggests an involvement of these structures in cell to cell adhesion (Davis \& Lewis 1981). Also, if the projections connect adjacent cells, they may facilitate the lateral water transport in the mesophyll (HeideJrgensen 1978) and/or provide a pathway of ionic movement, particularly that of potassium ions, from cell to cell (Carr et al. 1980). The hydrophilic prop- erties of pectic substances and their gelation behaviour (Morris et al. 1982) also suggest that the protuberances may play a role in the hydration of cell walls (Machado \& Sajo 1996) and in the maintenance of the structural tissue integrity (Morris et al. 1982). The lipophilic components of the protuberances may have a role in cell adhesion, suberization, and plant defence (Cutler 1966, Davis \& Lewis 1981).

In conclusion, the presence of these intercellular protuberances around the parenchyma cells of $P$. superbus leaves could be an important cell specialisation for the survival in adverse environments. However, further studies on a larger number of plants of this environment are necessary to determine if this structure occurs in other species.

Acknowledgements - We thank the Centro de Microscopia Eletrônica, IBB, UNESP, Campus de Botucatu for the technical assistance, and to Dr. Ana Maria Benko Iseppon for the species identification.

\section{References}

CARLQUIST, S. 1956. On the occurrence of intercellular pectic warts in Compositae. American Journal of Botany 43:425-429.

CARR, D.J., OATES, K. \& CARR, S.G.M. 1980. Studies on intercellular pectic strands of leaf palisade parenchyma. Annals of Botany 45:403-413.

CARR, S.G.M. \& CARR, D.J. 1975. Intercellular pectic strands in parenchyma: studies of plant cell walls by scanning electron microscopy. Australian Journal of Botany 23:95-105.

CUTLER, D.F. 1966. Anatomy and taxonomy of the Restionaceae. Notes from the Jodrell Laboratory 4:1-25.

DAVIES, W.P. \& LEWIS, B.G. 1981. Development of pectic projections on the surface of wound callus cells of Daucus carota L. Annals of Botany 47:409-413.

DUBOIS, T., GUEDIRA, M., DUBOIS, J. \& VASSEUR, J. 1991. Direct somatic embryogenesis in leaves of Cichorium. A histological and SEM study of early stages. Protoplasma 162:120-127.

DUbOIS, T., DUBOIS, J., GUEDIRA, M., DIOP, A. \& VASSEUR, J. 1992. SEM characterisation of an extracellular matrix around somatic proembryos in roots of Cichorium. Annals of Botany 70:119-124.

GIULIETTI, A.M. \& PIRANI, J.R. 1988. Patterns of geographic distribution of some plant species from the Espinhaço Range, Minas Gerais and Bahia, Brasil. In: Proceedings of a workshop of neotropical distribution patterns. Rio de Janeiro, p.39-69. 
HEIDE-JØRGENSEN, H.S. 1978. The xeromorphic leaves of Hakea suaveolens R. Br. 1. Structure of photosynthetic tissue with intercellular pectic strands and tylosoids. Svensk Botanisk Tidskrift 72:84-104.

JENSEN, W.A. 1962. Botanical histochemistry: principles and practice. Freeman, San Francisco.

KELLER, B. 1993. Structural cell wall proteins. Plant Physiology 101:1127-1130.

KONAR, R.N., THOMAS. E., \& STREET, H.E. 1972. Origin and structure of embryoides arising from epidermal cells of the stem of Ranunculus sceleratus L. Journal of Cell Science 11:77-93.

MACHADO, S.R. \& SAJO, M.G. 1996. Intercellular pectic protuberances in leaves of some Xyris species (Xyridaceae). Canadian Journal of Botany 74:1539-1541.

MORRIS, E.R., POWELL, D.A., GIDLEY, M.J. \& REES, D.A. 1982. Conformations and interactions of pectins. I. Polymorphism between gel and solid states of calcium polygalacturonate. Journal of Molecular Biology 155:507-516.
PARAMESWARAN, N. 1976. Intercellular strands between sclerotic phelloids in the lenticel of spruce bark. Protoplasma 87:447-451.

POTGIETER, M.J. \& VAN WYK, A.E. 1992. Intercellular pectic protuberances in plants: their structure and taxonomic significance. Botanical Bulletin of Academic Sinica 33:295-316.

RUOSLAHTI, E. \& PIERSCHBACHER, M.D. 1987. New perspectives in cell adhesion; RGD and integrins. Science 238:491-497.

SHOWALTER, A.M. 1993. Structure and function of plant cell wall proteins. The Plant Cell 5:9-23.

VERDUS, M.C., DUBOIS, T., DUBOIS, J. \& VASSEUR, J. 1993. Ultrastructural changes in leaves of Cichorium during somatic embryogenesis. Annals of Botany 72:375-383.

ZHANG, W.C., LI, R.Q., YAN, W.M. \& GAO, X.Y. 1998. Ultrastructural observations on the distribution of the intra-and intercellular cytoskeleton of the endosperm cells in Triticum aestivum. Acta Botanica Sinica 40:298-302. 